\title{
The Mercury Photosensitized Reaction of Dimethyl Ether
}

\author{
R. A. Marcus, B. deB. Darwent, and E. W. R. Steacie \\ Division of Chemistry, National Research Council, Ottawa, Canada
}

(Received June 1, 1948)

\begin{abstract}
The mercury photosensitized reaction of dimethyl ether has been investigated at pressures between 28 and $500 \mathrm{~mm}$ and at temperatures between $25^{\circ} \mathrm{C}$ and $292^{\circ} \mathrm{C}$. At $25^{\circ} \mathrm{C}$ the products consist almost entirely of hydrogen and 1,2* dimethoxyethane, and the initial step has been shown to be the abstraction of a hydrogen atom.

At higher temperatures $\mathrm{CH}_{2} \mathrm{O}, \mathrm{CH}_{4}, \mathrm{C}_{2} \mathrm{H}_{5}$ and probably $\mathrm{CH}_{3} \mathrm{OC}_{2} \mathrm{H}_{5}$ become important products. They are derived from the decomposition of the methoxy methyl radical followed by subsequent radical recombination reactions. Carbon monoxide is produced in the later stages from the decomposition of formaldehyde.
\end{abstract}

By varying the light intensity and pressure it has been shown that ethane and dimethoxyethane are produced by second order recombination of methyl and methoxy methyl radicals respectively. The activation energies of the following reactions have been estimated:

$$
\begin{array}{rl}
\mathrm{CH}_{3}+\mathrm{CH}_{3} \mathrm{OCH}_{3} \rightarrow \mathrm{CH}_{4}+\mathrm{CH}_{3} \mathrm{OCH}_{2} & E=9.0 \mathrm{kcal} . \\
\mathrm{CH}_{3} \mathrm{OCH}_{2} \rightarrow \mathrm{CH}_{3}+\mathrm{CH}_{2} \mathrm{O} & E=19 \mathrm{kcal} .
\end{array}
$$

the only assumption being that methyl and methoxy methyl radicals recombine with zero activation energy.

\section{INTRODUCTION}

$\mathrm{A}^{\mathrm{s}}$ $\mathrm{N}$ investigation ${ }^{1}$ of the mercury photosensitized reactions of diethyl ether showed that the initial step probably consists of the abstraction of a hydrogen atom resulting in the formation of the radical $\mathrm{C}_{2} \mathrm{H}_{5} \mathrm{O} \cdot \mathrm{C}_{2} \mathrm{H}_{4}$; however, the products were complex and the possibility that the reaction proceeded through the formation of an active ether molecule could not be excluded. The mercury photosensitized reactions of dimethyl ether, being simpler, should give more definite information about the nature of the primary act in these reactions of the simple ethers.

The only previous investigation of the photodecomposition of dimethyl ether is that of Berthelot and Gaudechon," who used the full light from a mercury lamp. This was most likely a photosensitized reaction since no precautions were taken to ensure the absence of mercury and since dimethyl ether is transparent to about $2000 \mathrm{~A}$. They reported methane, carbon monoxide, hydrogen and an unidentified liquid as the products, but their results were not sufficiently detailed to give information about the primary act.

This investigation has established the occurrence of a $\mathrm{C}-\mathrm{H}$ split and the formation of the radical $\mathrm{CH}_{3} \mathrm{OCH}_{2}$ as the initial step. The chain-

\footnotetext{
${ }^{1}$ B. deB. Darwent, E. W. R. Steacie, and A. F. Van Winckel, J. Chem. Phys. 14, 551 (1946).

2 D. Berthelot and H. Gaudechon, Comptes rendus 153, 383 (1911).
}

carrying steps in the thermal decomposition of dimethyl ether, as postulated by Rice and Herzfeld ${ }^{3}$ were :

$$
\begin{aligned}
\mathrm{CH}_{3} \mathrm{OCH}_{2} & \rightarrow \mathrm{CH}_{3}+\mathrm{CH}_{2} \mathrm{O}, \\
\mathrm{CH}_{3}+\mathrm{CH}_{3} \mathrm{OCH}_{3} & \rightarrow \mathrm{CH}_{4}+\mathrm{CH}_{3} \mathrm{OCH}_{2} .
\end{aligned}
$$

The present investigation has enabled an estimate to be made of the activation energies of these reactions.

\section{EXPERIMENTAL}

Dimethyl ether was obtained in cylinders from the Ohio Chemical and Manufacturing Company, Cleveland, Ohio. It was stated to be 99.97 percent pure and was used without further purification except for a simple bulb to bulb distillation and degassing by repeated freezing and melting in vacuum. It was stored as a liquid in a cooled vessel isolated by a mercury cut-off.

The reaction system was of conventional design in which the gases were circulated by a pump of the type described by Puddington ${ }^{4}$ through a mercury saturator, desaturator and a

TABLE I. Analysis of liquid product.

\begin{tabular}{lcccccc}
\hline & b.p. & $n_{D^{20}}$ & $n_{\beta^{20}-n_{\alpha}{ }^{20}}$ & $\% \mathrm{C}$ & $\%$ H & $\%$ O \\
\hline $\begin{array}{l}\text { Product } \\
\text { 1,2-dimethoxy } \\
\text { ethane }\end{array}$ & 84.8 & $\mathbf{1 . 3 7 9 6}$ & 0.00652 & $\mathbf{5 3 . 3}$ & 11.1 & $\mathbf{3 5 . 6}$ \\
\hline
\end{tabular}

${ }^{3}$ F. O. Rice and K. F. Herzfeld, J. Am. Chem. Soc. 56, 284 (1934).

I. E. Puddington, Ind. Eng. Chem. (Anal. Ed.) 17, 592 (1945). 
TABLE II. Mercury photosensitized decomposition of dimethyl ether.*

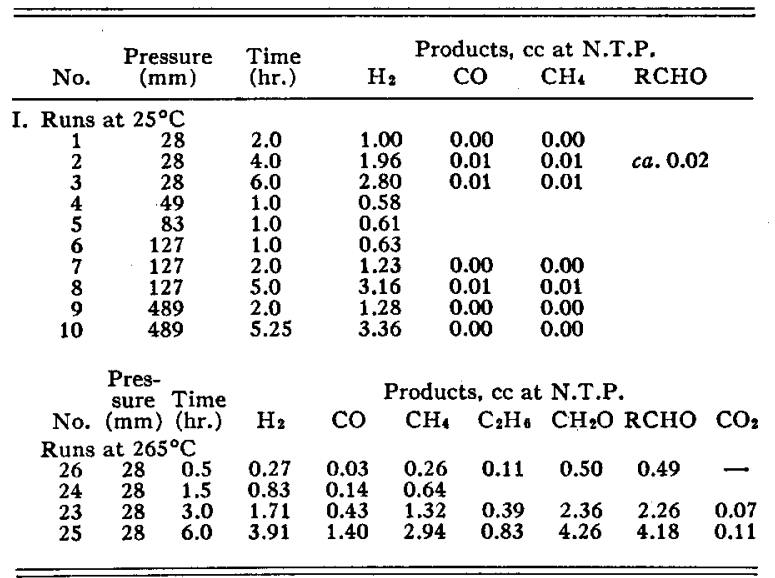

* Volume of system-3790 cc. Volume of reaction vessel-240 cc. Circulation rate $-300 \mathrm{cc} \mathrm{min.}^{-1}$ at prevailing pressure. $\lambda 2537$ absorbed $-c a .3 .5 \times 10^{-5}$ einstein $\mathrm{hr} .{ }^{-1} \mathrm{Hg}$ pressure $-1.5 \times 10^{-3} \mathrm{~mm}$.

cylindrical quartz reaction cell enclosed in a concentric tubular furnace. A large dead space was included in the system to lower the partial pressures of the products. This allowed appreciable amounts of products to be obtained even though the reaction was restricted to small conversions. Mercury cut-offs were used to separate the reaction system from the rest of the apparatus because of the high solubility of ether in stopcock grease. The total volume of the system was $3790 \mathrm{cc}$ and of the quartz reaction cell $240 \mathrm{cc}$.

The furnace temperature, controlled manually to $\pm 1^{\circ} \mathrm{C}$, was measured by a copper-constantan

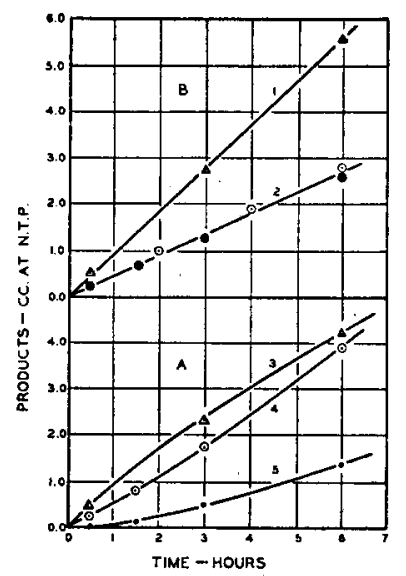

Fig. 1. The products of the reaction.

Curve $1-\mathrm{CH}_{2} \mathrm{O}+\mathrm{CO}$ at $265^{\circ} \mathrm{C}$. Curve 2--Open circles: $\mathrm{H}_{2}$ at $25^{\circ} \mathrm{C}$; filled Curve 3- $\mathrm{CH}_{2} \mathrm{O}$ at $265^{\circ} \mathrm{C}$. Curve $4-\mathrm{H}_{2}$ at $265^{\circ} \mathrm{C}$. thermocouple affixed to the rear face of the quartz cell. This in turn was calibrated against a similar couple placed inside the cell close to the incident face. The correction varied from $+3^{\circ} \mathrm{C}$ at $170^{\circ} \mathrm{C}$ to $+6^{\circ} \mathrm{C}$ at $265^{\circ} \mathrm{C}$, and was independent of the pressure of the circulating gas.

Unreversed $\lambda 2537$ was obtained from a low pressure mercury lamp with neon $(3 \mathrm{~mm})$ as carrier gas. It is reasonably certain that little $\lambda 1849$ entered the cell since the light path from the lamp, through a quartz furnace window, to the incident face of the reaction cell, was about $20 \mathrm{~cm}$ in air. The intensity of $\lambda 2537$ was estimated from the rate of hydrolysis of monochloracetic acid $(0.5 \mathrm{~N})$, by assuming a value of 0.315 for the quantum yield of the hydrolysis ${ }^{5}$ and applying a small correction for the dark reaction.

The products were largely hydrogen and 1,2dimethoxyethane ("dimer") at room temperature; at higher temperatures methane, ethane, formaldehyde, carbon monoxide and traces of carbon dioxide were also detected. Spot tests ${ }^{6}$ for alcohols and peroxides proved to be negative. A positive test ${ }^{7}$ for acetaldehyde was obtained, but determinations of the formaldehyde ${ }^{8}$ and total aldehydes ${ }^{9}$ showed that the acetaldehyde was present in negligible quantities. To eliminate errors inherent in the use of two different methods the former procedure, a colorimetric method, was calibrated against the latter. Negligible blanks were obtained when pure dimethyl ether was submitted to tests for the various products.

After given reaction times, the condensible products were immediately frozen out. The products were separated by pumping from a trap kept successively at $-183^{\circ} \mathrm{C},-135^{\circ} \mathrm{C}$ and $-100^{\circ} \mathrm{C}$. The products volatile at $-183^{\circ} \mathrm{C}$ $\left(\mathrm{CH}_{4}, \mathrm{CO}, \mathrm{H}_{2}\right)$ were analyzed by conventional methods. Some methane was retained by the substantial amount of solid dimethyl ether pres-

${ }^{5}$ R. N. Smith, P. A. Leighton, and W. G. Leighton, J. Am. Chem. Soc. 61, 2299 (1939).

${ }^{B}$ F. Feigl, Qualitative Analysis by Spot Tests (Elsevier Publishing Company, New York, 1946).

7 A. Ley, J. Pharm. chim. (6) 22, 107 (1897).

8 D. Matuakawa, J. Biochem. (Tokyo) 30, 386 (1939).

${ }^{9}$ I. M. Kolthoff and N. H. Furman, Volumetric Analysis (John Wiley and Sons, Inc., New York, 1929), Vol. II, p. 450 . 
ent, but this was removed by repeated meiting, freezing and pumping.

The gas volatile at $-135^{\circ} \mathrm{C}$, a mixture of ethane and methyl ether with traces of $\mathrm{CO}_{2}$ and $\mathrm{CH}_{2} \mathrm{O}$, was analyzed in a modification ${ }^{10}$ of the Ward ${ }^{11}$ fractionation system. In the early runs, the ethane was identified by combustion over a hot platinum wire. No ethylene was detected. A small " $\mathrm{C}_{3}$ " fraction, analyzed by combustion, proved to be a mixture of $\mathrm{CO}_{2}$ and dimethyl ether. The presence of $\mathrm{CO}_{2}$ was further established with the limewater test.

The fraction volatile at $-100^{\circ} \mathrm{C}$ consisted of $\mathrm{CH}_{2} \mathrm{O}$ and the bulk of the ether. The residue remaining in the trap, liquid at room temperature, was frozen out in a small pycknometer $(3.35 \pm 0.05) \times 10^{-3} \mathrm{cc} \mathrm{cm}^{-1}$ attached to the trap by a mercury cut-off. The dead space above the pycknometer, $0.15 \mathrm{cc}$, ensured only a small correction for the amount of material in the vapor phase. The amount of liquid was estimated after standing for several hours at room temperature. Prior to this, the liquid at no time came in to contact with stopcock grease.

This fraction was identified by its boiling point, refractive index, and carbon, hydrogen and oxygen analysis.* The properties of the liquid product, given in Table I, are compared with those of 1,2-dimethoxy ethane. In reporting the "dimer" in subsequent tables, its quantity has been expressed as cc of gas at N.T.P. on the assumption that its molecular weight corresponds to that of 1,2-dimethoxy ethane.

The latter two fractions, volatile at $-100^{\circ} \mathrm{C}$, and residue, were combined, and frozen out in a tube containing ice which was sealed off and the formaldehyde content determined by the bisulphite method. ${ }^{9}$ This value was corrected for the amount (av. 2 percent) present in the second fraction.

Finally, blank experiments in the dark showed that the thermal decomposition of dimethyl ether and products was negligible at all temperatures employed in this investigation.

${ }^{10}$ J. J. Savelli, W. D. Seyfried and B. M. Filbert, Ind. Eng. Chem. (Anal. Ed.) 13, 868 (1941).

${ }_{11}$ E. C. Ward, Ind. Eng. Chem. (Anal. Ed.) 10, 169 (1938).

* We are indebted to Dr. L. Marion of this Laboratory for the $\mathrm{C}: \mathrm{H}$ analyses.
TABLE III. Mercury photosensitized decomposition of dimethyl ether.*

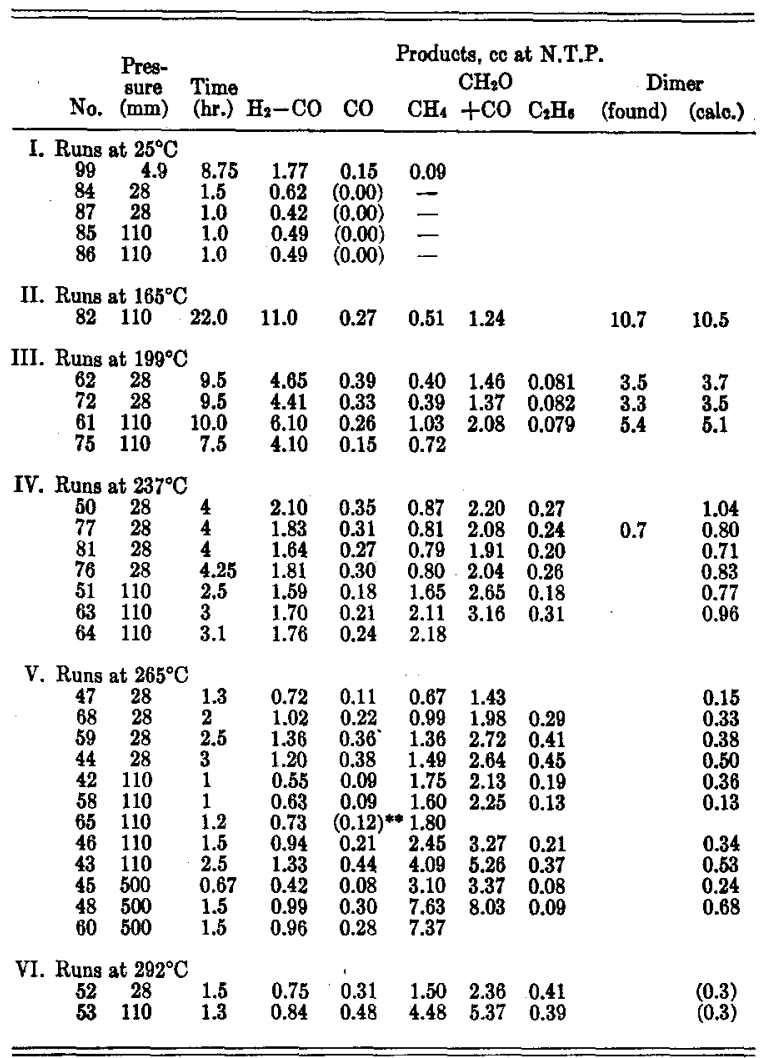

* Conditions as in Table II, but light input-2.7 $\times 10^{-5}$ einstein $\mathrm{hr} .^{-1}$ * Interpolated.

\section{RESULTS}

The results of preliminary experiments to investigate the effects of time and ether pressure on the nature of the products of the mercury photosensitized reactions of dimethyl ether at $25^{\circ} \mathrm{C}$ and $265^{\circ} \mathrm{C}$ are given in Table II of which column 7 , headed RCHO, denotes total aldehydes. Inspection of these data shows that, at $25^{\circ} \mathrm{C}$ and between 28 and $489 \mathrm{~mm}$, hydrogen (and presumably 1,2-dimethoxy ethane) are the only important products, and that the rate of production of hydrogen is independent of time

TABLE IV.*

\begin{tabular}{|c|c|c|c|c|c|c|c|c|}
\hline No. & $\begin{array}{l}\text { Time } \\
\text { (hr.) }\end{array}$ & $\mathrm{H}_{2}-\mathrm{CO}$ & $\mathrm{CO}$ & $\begin{array}{l}\text { Prod } \\
\mathrm{CH}_{4}\end{array}$ & $\begin{array}{l}\mathrm{ts}, \mathrm{cc} \text { at } \\
\mathrm{CH}_{2} \mathrm{O} \\
+\mathrm{CO}\end{array}$ & $\begin{array}{l}\text { V.T.P. } \\
\mathrm{C}_{2} \mathrm{H}_{6}\end{array}$ & (found) & $\begin{array}{l}\text { ner } \\
\text { (calc.) }\end{array}$ \\
\hline $\begin{array}{l}78 \\
79 \\
80\end{array}$ & $\begin{array}{l}22 \\
48.5 \\
48.5\end{array}$ & $\begin{array}{l}0.96 \\
1.72 \\
1.76\end{array}$ & $\begin{array}{l}0.39 \\
1.17 \\
1.20\end{array}$ & $\begin{array}{l}1.82 \\
3.17 \\
3.40\end{array}$ & $\begin{array}{l}2.63 \\
4.58 \\
4.75\end{array}$ & $\begin{array}{l}0.25 \\
0.37 \\
0.35\end{array}$ & $\begin{array}{l}0.2 \\
0.5 \\
0.5\end{array}$ & $\begin{array}{l}0.40 \\
0.68 \\
0.76\end{array}$ \\
\hline
\end{tabular}

* Conditions as in Table II, but light input $=2.2 \times 10^{-6}$ einstein $\mathrm{hr}$ - $^{-1}$ Temp.-. $237^{\circ} \mathrm{C}$; Pressure $-28 \mathrm{rom}$. 
TABLE V. Effect of light intensity on methane and ethane formation at $237^{\circ} \mathrm{C}$.

\begin{tabular}{cccc}
\hline \hline & $\begin{array}{c}\text { Light input } \\
\text { (einstein } \\
\left.\text { ho. }{ }^{-1} \times \mathbf{1 0}^{8}\right)\end{array}$ & ${ }^{k} \mathrm{CH}_{4}{ }^{/ k} \mathrm{C}_{2} \mathrm{H}_{6}{ }^{3}$ & ${ }^{k} \mathrm{CH}_{4} /{ }^{k} \mathrm{C}_{2} \mathrm{H}_{8}$ \\
\hline 50 & 27 & 0.84 & 3.2 \\
76 & 27 & 0.78 & 2.8 \\
77 & 27 & 0.84 & 3.1 \\
81 & 27 & 0.89 & 4.0 \\
& & Av. 0.81 & Av. 3.3 \\
78 & 2.2 & 0.78 & 7.4 \\
79 & 2.2 & 0.76 & 8.7 \\
80 & 2.2 & 0.82 & 9.7 \\
& & Av. 0.79 & Av. 8.6 \\
\hline
\end{tabular}

(Fig. 1), but increases with ether pressure up to about $100 \mathrm{~mm}$, probably as a result of incomplete quenching, above which pressure the rate is pressure independent and quenching is essentially complete. At $265^{\circ} \mathrm{C}, \mathrm{CO}, \mathrm{CH}_{4}, \mathrm{C}_{2} \mathrm{H}_{6}$ and $\mathrm{CH}_{2} \mathrm{O}$ become important products. The data in Table II show that at $265^{\circ} \mathrm{C}$ rates of formation of $\mathrm{CH}_{4}$ and $\mathrm{C}_{2} \mathrm{H}_{6}$ are independent of time but that the rate of formation of $\mathrm{H}_{2}$ increases with time and is paralleled by a corresponding increase in the rate of formation of $\mathrm{CO}$ and by a decrease in the rate of formation of $\mathrm{CH}_{2} \mathrm{O}$; this is illustrated in Fig. 1(a). If it be assumed that this deviation from linearity is due to decomposition of the formaldehyde:

$$
\mathrm{CH}_{2} \mathrm{O} \rightarrow \mathrm{CO}+\mathrm{H}_{2}
$$

then the rates of formation of $\left(\mathrm{H}_{2}-\mathrm{CO}\right)$ and of $\left(\mathrm{CH}_{2} \mathrm{O}+\mathrm{CO}\right)$ should be independent of time; Fig. 1(b) shows clearly that those rates are in fact independent of time and that the rate of formation of $\left(\mathrm{H}_{2}-\mathrm{CO}\right)$ at $265^{\circ} \mathrm{C}$ is the same as the rate of production of hydrogen at $25^{\circ} \mathrm{C}$,

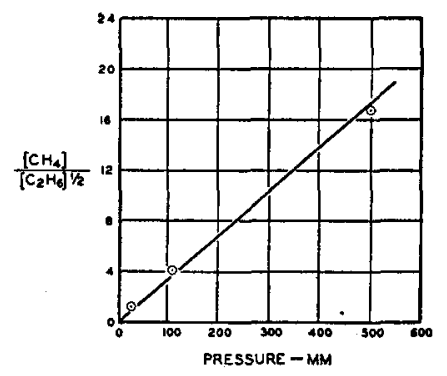

Fig. 2. Variation of methane-ethane ratio with pressure at $237^{\circ} \mathrm{C}$. Each point represents the average of all runs.
TABLE VI. Effect of light intensity on $\mathrm{CH}_{2} \mathrm{O}$ and dimer.

\begin{tabular}{cccc}
\hline \hline & $\begin{array}{c}\text { Light input } \\
\text { (einstein } \\
\left.\text { hr }{ }^{-1} \times 10^{6}\right)\end{array}$ & $\begin{array}{c}{\left[\mathrm{CH}_{2} \mathrm{O}+\mathrm{CO}\right] /} \\
\text { [dimer] }\end{array}$ & $\begin{array}{c}{\left[\mathrm{CH}_{2} \mathrm{O}+\mathrm{CO}\right] /} \\
{[\text { dimer] }}\end{array}$ \\
\hline 50 & 27 & 1.06 & 2.1 \\
76 & 27 & 1.04 & 2.5 \\
77 & 27 & 1.16 & 2.6 \\
81 & 27 & 1.13 & 2.7 \\
& & Av. 1.10 & Av. 2.5 \\
78 & 2.2 & 0.90 & 6.7 \\
79 & 2.2 & 0.81 & 6.8 \\
80 & 2.2 & 0.79 & 6.3 \\
& & Av. 0.83 & Av. 6.6 \\
\hline
\end{tabular}

indicating that the production of hydrogen in the initial stage is temperature independent.

The results of experiments to determine the effect of temperature on the products of the reaction are given in Table III. Here the production of hydrogen and formaldehyde are corrected for the decomposition of formaldehyde and are quoted as $\left(\mathrm{H}_{2}-\mathrm{CO}\right)$ and $\left(\mathrm{CH}_{2} \mathrm{O}+\mathrm{CO}\right)$ respectively, and, since the amount of $\mathrm{CO}$ produced is listed the uncorrected figures for $\mathrm{H}_{2}$ and $\mathrm{CH}_{2} \mathrm{O}$ may be obtained. The amount of "dimer" $\left(\mathrm{CH}_{3} \mathrm{OCH}_{2}\right)_{2}$ calculated from a material balance may be compared in some experiments with the amounts actually found; the agreement is shown to be satisfactory. Material balance calculations show that the $\mathrm{C}: \mathrm{O}$ ratio of the products is less than the value of $2: 1$ in dimethyl ether. If ethane and dimer are formed by radical recombination then a logical additional product would be methyl ethyl ether with a $\mathrm{C}: \mathrm{O}$ ratio of $3: 1$. The presence of this product has been assumed and its amount can be calculated from the stoichiometric equations :

$$
\begin{aligned}
2\left(\mathrm{CH}_{3}\right)_{2} \mathrm{O} & \rightarrow \mathrm{H}_{2}+\left(\mathrm{CH}_{3} \mathrm{OCH}_{2}\right)_{2} \\
2\left(\mathrm{CH}_{3}\right)_{2} \mathrm{O} & \rightarrow \mathrm{C}_{2} \mathrm{H}_{6}+2 \mathrm{CH}_{2} \mathrm{O}+\mathrm{H}_{2} \\
\left(\mathrm{CH}_{3}\right)_{2} \mathrm{O} & \rightarrow \mathrm{CH}_{4}+\mathrm{CH}_{2} \mathrm{O} \\
2\left(\mathrm{CH}_{3}\right)_{2} \mathrm{O} & \rightarrow \mathrm{CH}_{3} \mathrm{OC}_{2} \mathrm{H}_{5}+\mathrm{CH}_{2} \mathrm{O}+\mathrm{H}_{2} \\
\mathrm{CH}_{2} \mathrm{O} & \rightarrow \mathrm{CO}+\mathrm{H}_{2}
\end{aligned}
$$

from which

$$
\begin{aligned}
\mathrm{CH}_{3} \mathrm{OC}_{2} \mathrm{H}_{5} & =\left(\mathrm{CH}_{2} \mathrm{O}+\mathrm{CO}\right)-\mathrm{CH}_{4}-\mathrm{C}_{2} \mathrm{H}_{6} \\
\left(\mathrm{CH}_{3} \mathrm{OCH}_{2}\right)_{2}= & \left(\mathrm{H}_{2}-\mathrm{CO}\right)+\mathrm{CH}_{4}+\mathrm{C}_{2} \mathrm{H}_{6} \\
& -\left(\mathrm{CH}_{2} \mathrm{O}+\mathrm{CO}\right) .
\end{aligned}
$$

On this basis, the calculated pressure increase for experiment 25 is $1.50 \pm 0.05 \mathrm{~mm}$, while the 
observed value was $1.55 \pm 0.05 \mathrm{~mm}$. The calculated and experimentally determined values of dimer are compared in the final column of Tables III and IV. The agreement is excellent when the amount of dimer is not so small that experimental losses become important.

\section{Quantum Yield}

At room temperature the quantum yield for ether reacted was determined to be 1.60 under conditions of complete quenching. The lamp emits some light other than $\lambda 2537$ which is active in the hydrolysis of monochloroacetic acid. The amount, however, is small, and the error in the quantum yield is not over 10 percent.

At $292^{\circ} \mathrm{C}$ and with an ether pressure of 110 $\mathrm{mm}$, the calculated amount of ether reacted is $2.1 \times 10^{-4}$ mole $\mathrm{hr}^{-1}$, so that under these conditions, a quantum yield of 8 is found.

In some experiments the light intensity was reduced by altering the current to the lamp. The effect on the products of a twelvefold change of intensity is given in Table IV.

\section{DISCUSSION}

\section{(a) The Photosensitized Reaction}

The great preponderance of hydrogen and 1,2-dimethoxy ethane in the products at $25^{\circ} \mathrm{C}$ is explained adequately by the reactions: $\mathrm{CH}_{3} \mathrm{OCH}_{3}+\mathrm{Hg}\left({ }^{3} \mathrm{P}_{1}\right) \rightarrow$

$$
\begin{aligned}
\mathrm{CH}_{3} \mathrm{OCH}_{2}+\mathrm{H}+\mathrm{Hg}\left({ }^{(} \mathrm{S}_{0}\right) & \\
\mathrm{H}+\mathrm{CH}_{3} \mathrm{OCH}_{3} & \rightarrow \mathrm{CH}_{3} \mathrm{OCH}_{2}+\mathrm{H}_{2} \\
2 \mathrm{CH}_{3} \mathrm{OCH}_{2} & \rightarrow\left(\mathrm{CH}_{3} \mathrm{OCH}_{2}\right)_{2} .
\end{aligned}
$$

The reaction rate does not decrease with increasing pressure above $100 \mathrm{~mm}$ and there is no evidence for collisional deactivation, or for the formation of an excited molecule in the primary step. Reaction (2) has been shown ${ }^{12}$ to proceed rapidly at room temperature and probably represents the sole means of formation of hydrogen in those experiments since the experimental quantum yield of 1.6, a minimum value, compares favorably with the predicted value of 2.0 . The fact that reaction (3), and not a first-order recombination of methoxy methyl radicals on the

${ }^{12}$ W. R. Trost, B. deB. Darwent and E. W. R. Steacie, J. Chem. Phys. 16, 353 (1948).

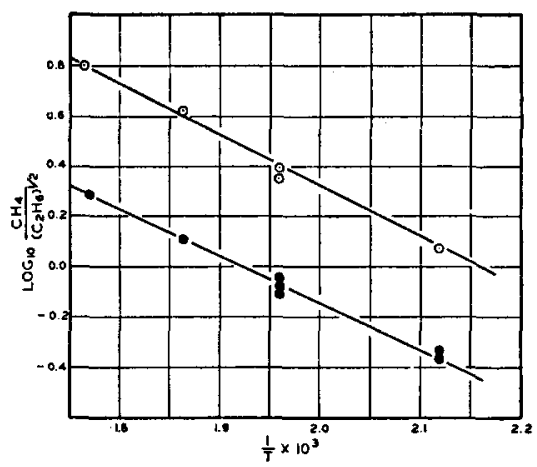

FIG. 3. Effect of temperature on $\mathrm{CH}_{4}$ and $\mathrm{C}_{2} \mathrm{H}_{6}$ production. Open circles: runs at $110 \mathrm{~mm}$; filled circles: runs at $28 \mathrm{~mm}$.

wall, represents the mode of formation of $1,2-$ dimethoxy ethane will be discussed later. The very small amounts of aldehydes and other products found indicate that reactions of the "atomic cracking" type do not occur significantly.

These results indicate the probability that diethyl ether ${ }^{1}$ also reacted with $\mathrm{Hg}\left({ }^{3} \mathrm{P}_{1}\right)$ atoms by a $\mathrm{C}-\mathrm{H}$ split. Re-examination of the results of that investigation shows that, at the higher pressures, no $\mathrm{CH}_{4}$ or $\mathrm{CO}$ are produced initially, and that any differences between the types of products obtained previously with diethyl ether and those now reported at room temperature, probably are due to the higher intensity used with diethyl ether, resulting in higher radical concentrations, leading to an increase in the "atomic cracking" type of reaction.

At higher temperatures additional products $\mathrm{CH}_{4}, \mathrm{C}_{2} \mathrm{H}_{6}, \mathrm{CO}$ and $\mathrm{CH}_{2} \mathrm{O}$ are formed in increasing amounts. These undoubtedly arise from the decomposition of the methoxy methyl radical ;

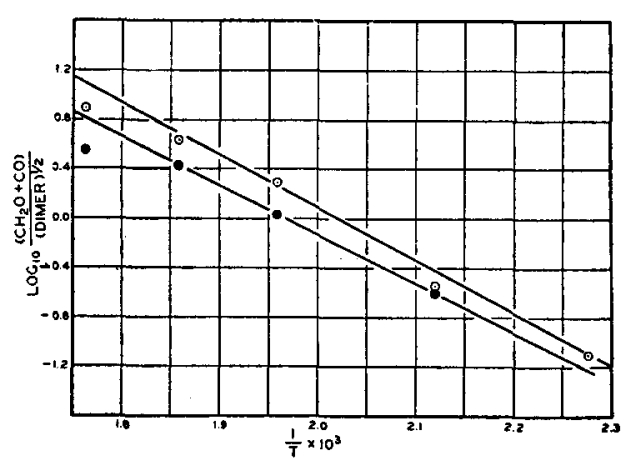

FIG. 4. The effect of temperature on the production of formaldehyde and dimer. Open circles: runs at $110 \mathrm{~mm}$; filled circles: runs at $28 \mathrm{~mm}$. 
they are not due to increased "atomic cracking" since the rate of production of methane at $265^{\circ} \mathrm{C}$ increases markedly with increasing ether pressure (Table III). It is also significant that the corrected value $\left(\mathrm{H}_{2}-\mathrm{CO}\right)$ for the rate of production of hydrogen is unaltered by an increase of temperature from $25^{\circ}$ to $265^{\circ} \mathrm{C}$ (Fig. 1), indicating that reaction (1) is, as expected, temperature independent and that, even at $25^{\circ} \mathrm{C}$, all $\mathrm{H}$ atoms produced eventually react with ether, as indicated by reaction (2).

\section{(b) The decomposition of $\mathrm{CH}_{3} \mathrm{OCH}_{2}$ and the reaction between $\mathrm{CH}_{3}$ and $\mathrm{CH}_{3} \mathrm{OCH}_{3}$}

The results show that the quantum yield of ether disappearance increases from 1.6 at $25^{\circ} \mathrm{C}$ to 8 at $295^{\circ} \mathrm{C}$; a chain reaction is therefore involved. Also at elevated temperatures $\mathrm{CH}_{4}, \mathrm{C}_{2} \mathrm{H}_{6}$ and $\mathrm{CH}_{2} \mathrm{O}$ are formed in increasing amounts. The chain carrying steps proposed by Rice and Herzfeld $^{3}$ for the thermal decomposition of dimethyl ether:

$$
\begin{gathered}
\mathrm{CH}_{3} \mathrm{OCH}_{2} \rightarrow \mathrm{CH}_{3}+\mathrm{CH}_{2} \mathrm{O} \\
\mathrm{CH}_{3}+\mathrm{CH}_{3} \mathrm{OCH}_{3} \rightarrow \mathrm{CH}_{3} \mathrm{OCH}_{2}+\mathrm{CH}_{4}
\end{gathered}
$$

together with the usual recombination steps:

$$
\begin{aligned}
2 \mathrm{CH}_{3} & \rightarrow \mathrm{C}_{2} \mathrm{H}_{6} \\
\mathrm{CH}_{3}+\mathrm{CH}_{2} \mathrm{OCH}_{3} & \rightarrow \mathrm{C}_{2} \mathrm{H}_{5} \mathrm{OCH}_{3}
\end{aligned}
$$

and reaction (3) account for the nature of the products and the increased quantum yield at elevated temperatures. As mentioned previously $\mathrm{CO}$ is produced by secondary decomposition of formaldehyde and enters the kinetics only as a correction term in the production of hydrogen and formaldehyde. On the basis of reactions (4) and (5) we get

and

$$
d / d t\left[\mathrm{CH}_{2} \mathrm{O}\right]=k_{4}\left[\mathrm{CH}_{3} \mathrm{OCH}_{2}\right]
$$

$$
d / d t\left[\mathrm{CH}_{4}\right]=k_{5}\left[\mathrm{CH}_{3}\right]\left[\mathrm{CH}_{3} \mathrm{OCH}_{3}\right]
$$

To evaluate $E_{4}$ and $E_{5}$, the corresponding activation energies, it is necessary to know the effect of temperature on $\left[\mathrm{CH}_{3} \mathrm{OCH}_{2}\right]$ and $\left[\mathrm{CH}_{3}\right]$, which are reflected in the rates of formation of 1,2-dimethoxy ethane and ethane respectively. However, these compounds may have been formed either by the second order processes (3) and (6) or by first order recombination on the wall :

$$
\begin{gathered}
\mathrm{CH}_{3} \mathrm{OCH}_{2} \stackrel{\text { wall }}{\rightarrow \frac{1}{2}\left(\mathrm{CH}_{3} \mathrm{OCH}_{2}\right)_{2},} \\
\mathrm{CH}_{3} \stackrel{\text { wall }}{\rightarrow \frac{1}{2}} \mathrm{C}_{2} \mathrm{H}_{6} .
\end{gathered}
$$

The rate of ethane formation is given by the equation

$$
\left\{d / d t\left[\mathrm{C}_{2} \mathrm{H}_{6}\right]=k_{6}\left[\mathrm{CH}_{3}\right]^{2} .\right.
$$

Thus at a given time we have,

$$
\frac{d / d t\left[\mathrm{CH}_{4}\right]}{\left(d / d t\left[\mathrm{C}_{2} \mathrm{H}_{6}\right]\right)^{\frac{1}{3}}}=\frac{k_{5}}{k_{6}^{\frac{3}{2}}}\left[\mathrm{CH}_{3} \mathrm{OCH}_{3}\right] \text {. }
$$

This relation demands that $\left(k \mathrm{CH}_{4} / k \mathrm{C}_{2} \mathrm{H}_{6}{ }^{\frac{1}{2}}\right)$ (1) be independent of radical concentration, i.e. of light intensity and (2) increase linearly with dimethyl ether pressure. The approximate validity of these assumptions are shown in Table $\mathrm{V}$ and in Fig. 2. In Table $V$ changing light intensity by a factor of twelve is seen to have no effect on the ratio $\left(k \mathrm{CH}_{4} / k_{2} \mathrm{H}_{6}{ }^{1}\right)$. The units of $\mathrm{CH}_{4}$ and $\mathrm{C}_{2} \mathrm{H}_{6}$ are $\mathrm{cc} \mathrm{hr} .^{-1}$.

First-order recombination of methyl radicals would necessitate that $k \mathrm{CH}_{4} / k \mathrm{C}_{2} \mathrm{H}_{6}$ be independent of light intensity, a conclusion in strong disagreement with the data given in Table V.

Other processes for methane formation, such as

$$
\begin{aligned}
2 \mathrm{CH}_{3} & \rightarrow \mathrm{CH}_{4}+\mathrm{CH}_{2} \\
\mathrm{CH}_{3}+\mathrm{H} & \rightarrow \mathrm{CH}_{4},
\end{aligned}
$$

or three-body recombination in the gas phase are excluded, either on the basis of the effect of pressure and light intensity on the $k \mathrm{CH}_{4} / k \mathrm{C}_{2} \mathrm{H}_{6}{ }^{\frac{1}{3}}$ ratio, or on the basis of the temperature-independent rate of production of $\left(\mathrm{H}_{2}-\mathrm{CO}\right)$.

The rates of formation of formaldehyde and dimer are given by

$$
\begin{aligned}
d / d t\left[\mathrm{CH}_{2} \mathrm{O}+\mathrm{CO}\right] & =k_{4}\left[\mathrm{CH}_{3} \mathrm{OCH}_{2}\right] \\
d / d t[\text { dimer }] & =k_{3}\left[\mathrm{CH}_{3} \mathrm{OCH}_{2}\right]^{2} .
\end{aligned}
$$

Thus at any given reaction time,

$$
\left[\mathrm{CH}_{2} \mathrm{O}+\mathrm{CO}\right] /[\text { dimer }]^{\frac{1}{3}}=k_{4} / k_{3^{3}} \text {. }
$$

The effect of light intensity on the ratio of these products is given in Table VI.

The ratio $\left[\mathrm{CH}_{2} \mathrm{O}+\mathrm{CO}\right] /[\text { dimer }]^{\frac{1}{2}}$ is approximately independent of intensity as demanded by the second order recombination process, whereas the ratio $\left[\mathrm{CH}_{2} \mathrm{O}+\mathrm{CO}\right] /[$ dimer $]$ is quite strongly 
dependent on intensity. Hence it is evident that the formation of "dimer" is a second-order process. The apparent slight dependence of the ratio $\left[\mathrm{CH}_{2} \mathrm{O}+\mathrm{CO}\right] /[\text { dimer }]^{\frac{1}{3}}$ on intensity is probably due to increased polymerization of the formaldehyde in the long runs at low intensity.

\section{Activation Energies}

The slopes of the plot $\log \left(k \mathrm{CH}_{4} / k \mathrm{C}_{2} \mathrm{H}_{6}{ }^{\frac{1}{2}}\right)$ vs. $1 / T$, given in Fig. 3, correspond to activation energies of 8.8 at $28 \mathrm{~mm}$, and 9.2 at $110 \mathrm{~mm}$. On the basis of the previous discussion this is equal to $E_{5}-\frac{1}{2} E_{6}$. Assuming $E_{6}$, the activation energy for recombination of two methyls, to be zero, the activation energy for the reaction of methyl radicals with dimethyl ether $\left(E_{5}\right)$ is equal to 9.0 kcal. Similarly, from a plot of $\log \left[\mathrm{CH}_{2} \mathrm{O}+\mathrm{CO}\right] /$ [dimer $]^{\frac{k}{t}}$ vs. $1 / T$, given in Fig. 4 , the activation energy for the unimolecular decomposition of the $\mathrm{CH}_{3} \mathrm{OCH}_{2}$ radical is equal to 18.5 and 20.0 $\mathrm{kcal}$. at $28 \mathrm{~mm}$ and $110 \mathrm{~mm}$ respectively, and if the activation energy for the recombination of two methoxy-methyl radicals is assumed to be zero, then $E_{4}$ may be taken as $19 \mathrm{kcal}$. In plotting the curves in Fig. 4, the runs at the highest temperature have been given little weight, since experimental errors are much larger at the highest temperatures.

\title{
Isotope Effect in the Thermal Cracking of Propane-1-C ${ }^{13}$
}

\author{
D. P. Stevenson, C. D. Wagner, O. Beeck, and J. W. Otvos \\ Shell Development Company, Emeryville, California
}

(Received June 21, 1948)

$\mathbf{I}^{\mathrm{T}}$ $T$ was recently found that the dissociation probabilities of the $\mathrm{C}^{12}-\mathrm{C}^{12}$ and the $\mathrm{C}^{12}-\mathrm{C}^{13}$ bonds of the molecule-ions formed from propane$1-\mathrm{C}^{13}$ by electron impact differ by $c a .20$ percent. ${ }^{1}$ This observation led us to look for a similar difference in ordinary chemical reactions of propane- $1-\mathrm{C}^{13}$. The pyrolysis of propane was selected for study, since this reaction is one whose mechanism is presumably well understood. ${ }^{2}$ Significant differences were found in the reactivities of bonds to terminal $\mathrm{C}^{13}$ and $\mathrm{C}^{12}$ atoms. The magnitude of the effect, 8 percent more frequent rupture of $\mathrm{C}^{12}-\mathrm{C}^{12}$ bonds than of $\mathrm{C}^{12}-\mathrm{C}^{13}$ bonds,

TABLE I. Composition of feed propane-1-C ${ }^{13}(53 \%)$.

\begin{tabular}{cc}
\hline \hline Species & Mole fraction \\
\hline $\mathrm{C}^{12} \mathrm{H}_{3} \mathrm{C}^{12} \mathrm{H}_{2} \mathrm{C}^{12} \mathrm{H}_{3}$ & $0.457_{5} \pm .0015$ \\
$\mathrm{C}^{12} \mathrm{H}_{3} \mathrm{C}^{12} \mathrm{H}_{2} \mathrm{C}^{13} \mathrm{H}_{3}$ & $.526_{5} \pm .0017$ \\
$\mathrm{C}^{12} \mathrm{H}_{3} \mathrm{C}^{13} \mathrm{H}_{2} \mathrm{C}^{12} \mathrm{H}_{3}$ & $.0048 \pm .0001$ \\
$\mathrm{C}^{12} \mathrm{H}_{3} \mathrm{C}^{13} \mathrm{H}_{2} \mathrm{C}^{13} \mathrm{H}_{3}$ & $.0056 \pm .0001$ \\
$\mathrm{C}^{13} \mathrm{H}_{3} \mathrm{C}^{12} \mathrm{H}_{2} \mathrm{C}^{13} \mathrm{H}_{3}$ & $.0056 \pm .0001$ \\
$\mathrm{C}^{13} \mathrm{H}_{3} \mathrm{C}^{13} \mathrm{H}_{2} \mathrm{C}^{13} \mathrm{H}_{3}$ & \\
\hline
\end{tabular}

${ }^{1}$ Beeck, Otvos, Stevenson, and Wagner, J. Chem. Phys. 16, 255 (1948).

2 E. W. R. Steacie, Atomic and Free Radical Reactions (Reinhold Publishing Corporation, New York, 1946). Particularly pages 103-105. is such that the effect should not be neglected in quantitative tracer experiments with carbon isotopes where reaction rates are involved.

Propane-1 $-\mathrm{C}^{13}$ (53 percent), prepared as previously described and with the isotopic species distribution shown in Table I, was cracked to a depth of approximately 10 percent (three separate experiments) at temperatures between 500 and $550^{\circ} \mathrm{C}$. The product was separated in to three fractions, hydrogen and methane, ethane, and ethylene, and propylene and propane, by one plate, isothermal distillation at very low pressure (low temperature). The relative concentrations of the isotopic methanes, ethylenes, and ethanes, as well as the total concentrations of hydrogen, methane, ethylene, ethane, propylene, and pro-

TABLE II, Mole fractions of "heavy" products.

\begin{tabular}{lcc}
\hline \hline & Found $\ddagger$ & $\begin{array}{c}\text { Calculated, } \\
\text { assuming no } \\
\text { isotope effect }\end{array}$ \\
\hline $\mathrm{C}^{13} \mathrm{H}_{4}$ in methane & $0.263 \pm .002$ & 0.272 \\
$\mathrm{C}^{12} \mathrm{C}^{13} \mathrm{H}_{4}$ in ethylene & $.288 \pm .004$ & .277 \\
$\mathrm{C}^{12} \mathrm{C}^{13} \mathrm{H}_{6}$ in ethane & $.252 \pm .010$ & .277 \\
\hline
\end{tabular}

t The original data were empirically corrected for mass dependent, ithe original data were empirically corrected for mass dependent, ion source discrimination effects. The indicated uncertainties are
mean deviations of analyses in three separate cracking experiments. 